Fifteen Minutes of Fame Long Gone: Circassian Activism before and after the Sochi Olympics

Bo Petersson and Karina Vamling

Faculty of Culture and Society, Malmö University, Malmö, Sweden

bo.petersson@mah.se, karina.vamling@mah.se 


\title{
Fifteen Minutes of Fame Long Gone: Circassian Activism before and after the Sochi Olympics
}

\begin{abstract}
In this article we discuss the effects of the Sochi Olympics on the indigenous Circassian population in North Caucasus. The Circassian situation was paradoxical in the sense that whereas this indigenous group fiercely opposed the organization of the Winter Games in Sochi, the Games themselves denoted a rare opportunity for them to make their voices heard internationally. During the run-up to the Olympics they all of a sudden had a global audience for their claims for recognition of their cause. This was quite simply their 'fifteen minutes of fame', a rare and short-lived period of celebrity and worldwide attention. The paper will look into whether the anti-Sochi activism helped to unite Circassians in the diaspora and abroad around common claims, and to what extent the Circassians managed to use media attention to make their cause more widely known by international society.
\end{abstract}

Keywords: Sochi Winter Olympic Games, Circassians, Circassian diaspora, genocide, recognition.

Before the Olympic Winter Games in Sochi in 2014 there was an intense discussion on Russia’s record on democracy and human rights, and whether it was appropriate to organize such a mega-event in an authoritarian setting. Similar voices were heard before the Beijing Summer Olympics in 2008. However, some kind of media logics always seems to dictate that once the Games start (see Ekberg and Strange, this issue), critical discussions are over and done with, and after the event the attention is gradually shifted to the next mega-event to follow. With regard to Sochi, as for all sites of major sports events in non-democratic settings, continued critical attention is however called for to assess political developments even, and perhaps especially, after the conclusion of the Games. Against this background, we will in this paper discuss how the organization of the Sochi Olympics influenced the indigenous Circassian population in North Caucasus, the activism for their cause and the global attention given to their demands. 
The Circassian situation was paradoxical in the sense that whereas this indigenous group for the most part intensely opposed the organization of the Winter Games in Sochi, the Games themselves denoted a rare opportunity for them to make their voices heard internationally. During the run-up to the Olympics they all of a sudden had a global audience, large segments of which were ready and prepared to listen while they communicated their claims for recognition of their cause (Hansen 2014). This was quite simply their fifteen minutes of fame, a rare and short-lived period of celebrity and worldwide attention (Petersson and Vamling 2013). Earlier research has indicated that marginalized and socially excluded groups as a rule do not profit from the organization of mega-events on their home ground (Minnaert 2012). Were the Circassians then any different in this regard? In this paper we will give special attention to the extent to which Circassian activity before the Sochi Games helped Circassians in the homeland and in the diaspora to articulate their claims, and to what extent the Circassians managed to use media attention to make their causes more widely known by the international society. For the sake of clarity, it should be added that we, when using the graphic expression of fifteen minutes of fame, have in mind precisely the brief period of rather unprecedented global attention for the Circassian cause. We certainly do not suggest, however, that the Circassian issue has lost its topicality, has been removed from the international agenda, or has been successfully resolved.

\section{Background and Setting}

Historically the Circassians fiercely opposed the Russian conquest of their part of the Caucasian region for more than one hundred years and up to Russia’s final victory in 1864 . Sochi was the last Circassian capital, and it has become a sacred place and a site of great symbolic value for the indigenous population and the Circassian diaspora. This is why so many Circassians were vocally critical of the idea of bringing the Olympic Games to Sochi (Bullough 2012). Especially provocative for them was the fact that the downhill competitions 
of the Games were to be located in the mountains, at Krasnaya Polyana, the very site where the Russians organized their victory parade in May 21, 1864. The grounds of Krasnaya Polyana hold many Circassian remains from those battles, which gave rise to Circassian protests under the slogan: 'No Olympics on our ancestors' graves' (Persson 2013). It added further insult to injury that the Olympic year of 2014 coincided with the 150th anniversary of the end of the Russo-Circassian war and the ensuing mass deportation of Circassians. In the last years of the war alone at least 625,000 Circassians out of a total population of 1.5 million are believed to have died (Richmond 2013, 92). According to one estimate, as much as a stunning 90\% of the Circassian population was killed during the 101 years between 1763 and 1864 in connection with the Russian campaign (Zhemukhov 2012, 505). Richmond (2013, 91) suggests that only in 1864 was the number of Circassians that were driven to the Black Sea coast for further deportation to the Ottoman Empire between 600,000 and 750,000. Among these the death tolls from starvation and sickness were staggering.

Substantial Circassian diasporas are today found in several countries, above all Turkey, Syria, Jordan, Israel and the US. In the homeland, situated in the Russian Federation, Circassians live in three areas of the North Caucasus: the republics of Adygeya, KarachaevoCherkessia and Kabardino-Balkaria. They are also found in North Ossetia and Stavropol krai and in some scattered villages on the Black Sea Coast ${ }^{1}$. According to the 2010 census (Vserossiiskaya perepis naseleniya 2010), the total number of Circassians (Adyghe, Cherkess Kabardians and Shapsugs) in the Russian Federation is today 719,000. The Circassian diaspora is several times bigger, but there are no reliable figures based on censuses (Besleney 2014). Estimates of the Circassian population in Turkey, which is the main country of Circassian diaspora settlement, vary considerably; Hansen (2013) mentions a span between

\footnotetext{
${ }^{1}$ In the years 1924-1945 this included a fourth Circassian autonomous territory, the Shapsug Cherkess.net National District (Polovinkina, undated).
} 
two and five million, whereas several other experts narrow the number down to between two and three million (Kaya 2014, 51; Papşu 2005; Besleney 2014, 31).

After the conquest in the mid-19th century the Russian strategy was to give the Circassians the option to resettle to Cossack-controlled areas on the plains north of the Caucasus or to emigrate. However, as Kreiten $(2009,219)$ notes, 'it was quite clear to Russian officials in the Caucasus that the Circassians would not leave their homeland voluntarily, but only when threatened with extermination.’ Following the Russian victory, most Circassians were forced into exile to the Ottoman Empire and remaining minor groups were dislocated to other places far away from their original settlements. Measures were taken early on to prevent exiled Circassians from returning. Already in 1861 rules were set up to counter return migration to the Caucasus: 'The purpose obviously was to exclude as many return candidates as possible by introducing a whole catalogue of conditions which could not easily be met' (Kreiten 2009, 222). The largest groups of Circassian emigrants to present-day Turkey came to live in the central and northwestern parts of the country. Thanks to their compact settlement in certain rural villages the Circassians for several generations largely managed to maintain their language and culture.

Contacts between Circassians in the homeland and in the diaspora became increasingly difficult in the early 1920s after the development of the new Soviet state and its increasing isolation, suspicion, repression and closed borders (Jaimoukha 2001, 75-76). During the 1930s many Circassian leaders and intellectuals in the homeland became victims of Stalin's purges. Under WWII the Circassian lands came under Nazi occupation (Jaimoukha 2001, 76-79). The Circassians' two co-titular groups, the Balkars and Karachais, were deported to Central Asia in 1944 (but were later rehabilitated under Khrushchev in 1957). Major political changes, basically favorable for the Circassians, took place in the region in the late $20^{\text {th }}$ and the beginning of the $21^{\text {st }}$ centuries. From having been expelled from 
their homeland, and thereafter regarding it as almost inaccessible, the prospect of return started to seem realistic for diaspora Circassians. Glasnost, perestroika and the collapse of the Soviet Union in 1991 opened up the borders and allowed for reinvigorated contacts with homeland Circassians. Popular political organizations were beginning to emerge in the North Caucasus, such as the Confederation of Caucasian Peoples, to which the Circassian Musa Shanibov was elected the first president (Besleney 2014, 91-92). Following the first international event in Ankara in 1989 to commemorate the exile, the International Circassian Association (ICA) was established in Nalchik in 1991, and became an important political actor and basis for transnational Circassian networking (Besleney 2014, 119). At much the same time Caucasian and Circassian associations became more active in Turkey, where legis lative changes were introduced in 2002 which gave organizations the right to get in touch with and join associations in foreign countries (Özgür 2011). The Federation of Caucasian Associations (KAFFED), an umbrella organization and central actor in Circassian diaspora politics in Turkey, developed close contacts with ICA and also largely came to share its proMoscow orientation that had increased over the years (Besleney 2014, 105).

Such was the background and the setting before the decision was taken by the International Olympic Committee in 2007 to hold the Olympic Winter Games in Sochi. Direct contacts and travel between the diaspora groups and the homeland in North Caucasus in the Russian Federation had become facilitated, the Circassian organizations in Turkey had become stronger and more active, and there was also vastly improved communication between and within different segments of the diaspora, on the one hand, and the homeland, on the other. At the same time, the internal political climate in Russia and the Caucasus was becoming increasingly tense. Important new actors in the Circassian diaspora responded to this situation. Among these were the Caucasus Forum (KF) in Turkey and the US-based Circassian Cultural Institute (later the International Circassian Council), demanding self- 
determination for the Circassians, repatriation to the Caucasus and the establishment of Circassia as a single entity in the Caucasus and launching campaigns to reach international recognition of the 'genocide' (Besleney 2014, 161-2).

The question for the Circassian movement in general was now how to become more visible and to strive for common aims (Lagunina 2007). In many ways it was the Sochi Olympics that provided the answer, as "it was the selection of Sochi for the Olympics that gave the activist groups the publicity boost that they needed” (Besleney 2014, 161).

\section{Circassian Activism: Framing and Symbolic Politics}

Charles Taylor (1994), in his treatise on the politics of recognition, famously differentiated between equality of respect and equality of dignity as the two key components of recognition. Whereas respect denotes equal value as fellow human beings, dignity is more connected to recognition of identity claims on a collective level, of the right to belong to a distinctive and unique community. In the Circassian case, one item in particular has of late become vital for the attempts of attaining global appreciation for the dignity and indeed the identity of the Circassians, namely the striving to have the atrocities of the Russian wars against the Circassians during the mid- $19^{\text {th }}$ century recognized as genocide.

As elaborated on by Zhemukhov (2012), Circassian activists form a heterogeneous group. Starting with the most radical sentiments, the Circassian movement could according to him be visualized on a scale ranging from vocal nationalists, who would demand a state of their own for the Circassians, over sovereigntists, culturalists and centrists onto accommodationists, the latter of whom strive for reaching a common understanding with the Russian authorities. In general, the most outspoken nationalists would be found in the diaspora, whereas most accommodationists would tend to be active in the homeland in 
contemporary Russia, where they have to co-exist on a daily basis with the powers-that-be in an increasingly authoritarian setting.

The recognition of what Circassians claim to be the genocide committed by the Russian Empire in the mid-19th century has ever since the end of the Cold War been one of the three professed main goals of Circassian activist groups in the diaspora, alongside the right of repatriation to the homeland and the unification of Circassian territories (Zhemukhov 2012, 505-506). Of these three, the recognition goal would seem to be the one politically most attainable in the short to medium time perspective, and it was thus to this goal that the main energy was devoted by activist groups during the years preceding the Sochi Olympics. In the words of Hansen $(2014,199)$, 'genocide recognition has become the new "banner" of the Circassian revival over the last couple of years'. The issue has attained symbolic value and has become a centerpiece of the identity construction of Circassian groups in the diaspora, and has come to make up the nexus of cooperation between the diaspora and the homeland (Hansen 2014). In other words, genocide recognition has come to be almost synonymous with the struggle for recognition of the Circassian identity as an indigenous population. If widely recognized by the international community, the recognition of the genocide could potentially and in the longer run lead to the articulation of demands for e.g. certain political rights, but this has thus most often not been the immediate focus of the activities. In any case, the attention awarded to the Sochi Olympics meant that Circassians were provided with a worldwide stage on which their demands for recognition of the genocide and thus their identity, albeit for a limited while, could be vocalized with much greater resonance.

Generally speaking, politically salient diaspora activities are today, much more so than in earlier ages, undertaken in manifold ways and through a myriad of different means. However, according to Hägel and Peretz $(2005,484)$, there are still three basic forms that such activities most often take: issue-framing, agenda-setting and network-building. By 
framing issues at hand differently from what incumbent regimes do, activists may challenge the hegemonic status of the powers-that-be. They do so by setting agendas that differ from those advocated by the incumbents. Through both national and transnational network-building these potentially oppositional ideas proliferate and attain additional strength and support.

On the concept of framing, Entman’s $(2004,5)$ influential definition denotes "selecting and highlighting some facets of events or issues, and making connections among them so as to promote a particular interpretation, evaluation and/or solution”. Frames perform functions such as problem definition, identification of causes, moral judgments and the recommendation of remedies. The framings made by elites are in all societies influential for shaping popular views and ideas, but counter-framings successfully propounded from the bottom and up can be salient oppositional politics with thorough implications for the definition of the political agenda.

Committed activist groups who, in the diaspora and at home, purposefully frame events differently from what certain government structures do and strive to gain acceptance and recognition for their interpretations could with good reason be regarded as transnational advocacy networks (Keck and Sikkink 1998). They are well organized for political ends and equipped with elaborate ideas about what strategies to follow (cf. Auten 2006). In the late 1990s Keck and Sikkink (1998,16-25) discerned four different tactics which advocacy networks tend to employ: information politics designed to generate credible and politically usable information; symbolic politics, i.e. the ability to evoke symbols, actions or stories that grasp the attention of far-away audiences; leverage politics which bring influence to bear on actors to change their behavior; and finally accountability politics which underscore discrepancies between stated aims and given promises, on the one hand, and actual behavior, on the other. Whereas all of these tactics seem relevant for the analysis and understanding of 
Circassian activism in relation to the Sochi Games, it is information politics and symbolic politics that are of special importance here.

The emergence and continuous development of information and communications technology (ICT) have served to revolutionize the contextual setting for activist groups, uniting efforts between diaspora groups and groups in the homeland, allowing for crisscrossing communication across and within different collective actors at different levels of scale. Both information and symbolic politics have become easier to effectuate, and the channels to spread the messages have proliferated. The global revolution in the modes of communication has enabled otherwise dispersed populations 'to converse, interact and even symbolize significant elements of their social and cultural lives’ (Gilroy 1994, 211).

Differently put, it has become 'much easier for diaspora groups to live on "both banks of the river” at the same time, both in diaspora and homeland' (Kaya 2004, 227).

In connection with the Sochi Olympics Circassian activists made substantial efforts both with regard to the questions of issue-framing and, on the basis of this, agenda-setting. The foremost examples pertain to the framing of the warfare of the Russian Empire in the mid-19th century as genocide against the Circassians, and the placing of the recognition of this genocide on the international agenda. As we will try to show in the following, Circassian activists employed both information politics and symbolic politics to this end, the two tactics of which tend to be patently difficult and even less meaningful, to pry apart as they most often are interwoven in practice. A particular message that is regarded as objective information by one party may be seen as heavily infested with emotional symbolism, or worse, by another.

Apart from the reaching out to global audiences there is also an internal dimension to this communication process. During the run-up to the Olympics, the growing number of publications, both on- and off-line, dealing with Circassian issues offered information that had previously not been known or accessible to larger groups. The documentation of 
Circassian history and the publication of books and materials on the Internet became an increasingly important task for Circassian communities and organizations, both among the diaspora and in the homeland in the Russian Federation (Besleney 2010, Hansen 2014). This contributed to the strengthening of a common identity among Circassians at home and abroad and helped strengthen the struggle for recognition of the Circassian genocide. The appearance of interactive technology and social media contributed to the easier spread of information and transnational contacts.

It can therefore be argued that the activities before the Olympics had a generally mobilizing effect among Circassians. The remarks by a Circassian activist about his gradual understanding of his own background are indicative of the importance of such publication activities:

[...] as a child growing up in Russia, he knew very little about his ancestry. Learning Circassian history was prohibited in school, he says. "When I was a child, it was if I was a guest in my own country. But slowly, I found some information about our history, and now I understand. I am a Circassian” (Somra and Watson 2014).

Overall, it seems that the Sochi issue brought different groups of the diaspora together and strengthened, not least through the establishment of the oppositional nosochi.com website, transnational interaction in the diaspora (Kaya 2014, Hansen 2014, Persson 2013). Vocally criticizing the organization of Olympics at the site of Sochi and adamantly pleading for an international boycott of the Games (Persson 2014), the website became a gathering point internally and was widely noticed externally. It attracted considerable international attention and became a platform for the Circassian efforts at constructing symbolic politics to promote their cause.

\section{Symbolism and Framing}


In 1992 and 1996, respectively, the parliaments of the two North Caucasian republics with the largest Circassian populations within the Russian Federation, Kabardino-Balkaria and Adygeya adopted resolutions on the Circassian genocide. In 1994, at the $130^{\text {th }}$ anniversary of the end of the war, President Boris Yeltsin characterized the Caucasian War of the 19th century as a 'courageous struggle by the Caucasian peoples not only for survival on their native lands but also for the maintenance of their own culture'. At the time he also expressed readiness to approach the problems of repatriation, whereby 'the return of the Caucasian emigrants to their historic homeland should be solved on an international level through negotiations between all parties concerned' (Adygi.ru 2011). Moreover, Yeltsin connected his readiness to comply with the simultaneous processes of construction of the rule of law and the prioritization of human values going on in Russia. This also coincided with the development of greater independence of the regional subjects of the Russian Federation, where Yeltsin famously encouraged the regions to 'take as much sovereignty as they could swallow' (New York Times 21 March, 1992).

As is well-known and in comparison with the turbulent but comparatively democratic years under Yeltsin, Vladimir Putin’s terms in presidential office from 1999/2000 have been characterized by the gradual re-emergence of authoritarian policies. The contextual preconditions for the Circassian struggle are therefore vastly different between then and now. This fact notwithstanding, Circassian organizations in May 2013 appealed, with no avail, to Putin and to the Federal Council of the Russian Federation to recognize the Circassian genocide by the Russian Empire during the Caucasian Wars (Adyge Heku 2013).

Some Circassian groups in the North Caucasian republics actually welcomed the idea of having Sochi as an Olympic host and saw possibilities in the worldwide attention and the investments the Games would attract (Gutkin 2014). They also hoped, in vain as it turned out, that the Circassians as the region's indigenous population would receive some kind of official 
acknowledgement during the Games. However, in his speech in Guatemala in 2007 when the decision was made to let Sochi organize the 2014 Winter Olympics, Vladimir Putin mentioned the ancient Greeks as inhabitants of old of the Sochi region but made no reference to the indigenous Circassians (YouTube 2007). As Richmond remarks the 'implication that the ancient Greeks were the first inhabitants at Sochi struck Circassians worldwide as the most blatant and public attempt yet to erase their history' (Richmond 2013, 149). The official and neglecting attitude towards the Circassians as an indigenous group was to prevail all through the run-up and the carrying through of the Games.

Circassian representatives were especially disappointed to be neglected also during the Olympic opening ceremony in Sochi (Kapaeva 2014). Apart from their participation in the general cultural program together with other ethnic groups of the Russian Federation and exhibitions in the so-called Circassian House in Krasnaya Polyana (Jaimoukha 2014), the Circassians were not present in any particular way. Moreover, in a statement by Vladimir Putin at a press conference during the Games not a single trace of acknowledgement of the legitimacy of the Circassian claims could be discerned. Instead, Putin stonewalled, arguing that the "Circassian factor" was used for undue attempts by the West to hamper and slow down developments in the Russian Federation in general:

We see [in the West] attempts to deter Russia here and there. Unfortunately, this had to do with the Olympic project and the Circassian factor was used as an instrument. However, frankly speaking, as soon as I realized that such attempts are being made I did not have any doubt that this was a futile attempt. I know what the mood is among the Circassians, I know the leaders of the Circassian organizations personally, and I know what their attitude is to both their native land and to their home country - Russia. It was obvious for me that this had no prospect (Putin, 2014).

Not only was there in Putin's speech a discernible attempt to connect the Circassian protests with the Western encirclement that used to be part of Soviet-time rhetoric and has been 
brought to life in an increasingly harsh political climate of $21^{\text {st }}$ century Putinism (Petersson and Sommers 2015). The argumentation also hints at condemning the Circassian demands as orchestrated from abroad and as the results of action by a fifth column inside the country. More recently, the activities of the foreign Circassian diaspora have even been labelled by the presidential administration as a potential threat to Russian national security (Kornya 2015). This all connotes a stern warning to the Circassian opposition not to rock the boat or else face the consequences. In Putin's speech there was also a visible tendency to dismiss the Circassian complaints by claiming that moderate and mainstream elements of the Circassians do not subscribe to the anti-Olympics activism. In this respect, Putin's statement was a demonstration of the classical politics of divide and rule.

\section{The Aftermath of the Games and the Genocide Issue}

Due to the dramatic developments in Ukraine in the spring of 2014 the Circassian issue disappeared from international news rather abruptly even before the Sochi Games had formally come to an end. At this very moment international media attention changed to focus on the political movement and increasing protests on the Maidan Square in Kyiv and the subsequent development in Crimea leading up to its annexation by Russia.

Obviously, the goal of making foreign countries boycott the Games, that was advocated e.g. by the nosochi2014 website $^{2}$, was not achieved. Moreover, as told and contrary to the expectations about some sort of official gesture during the ceremonies in Sochi, the Circassians did not get their recognition as the indigenous people of the Sochi region. Despite such setbacks, international experts such as Paul Goble still evaluated the Circassian achievements in a positive light:

\footnotetext{
2 The website was hacked shortly prior to the opening of the Games in Sochi (Bacchi 2014) and is not available on the internet anymore. Material by the nosochi2014 activists may be found on their Twitter (https://twitter.com/nosochi2014) and YouTube accounts (https://www.youtube.com/user/NoSochi2014).
} 
No nation more skillfully used an international event than did the Circassians during the Sochi Olympiad to call attention to the Russian-orchestrated genocide of their people 150 years earlier. Despite Moscow's best efforts, few independent reporters talked about Sochi without talking about the continuing crimes against the Circassians (Goble 2015).

Concerning the main symbolic issue of the recognition of the Circassian genocide, however, Georgia is so far the only foreign country to have complied with the request. This was made already in 2011 well ahead of the Sochi Games (Parliament of Georgia 2011). In the harsher political climate in Russia in the wake of the Ukrainian crisis and the reactions of the West to the Russian meddling, the Circassians have continued their activities aiming at international recognition of the genocide. In 2014 Circassian activists sent two appeals to Ukraine seeking official recognition. The first appeal (in May) was initiated by an Israeli-based Circassian organization whereas the second appeal (in June) was organized by Circassians in the North Caucasus and abroad. The appeals had some success as the Ukrainian MP Oleg Lyashko initiated a bill to be put before the Ukrainian Rada proposing recognition (Dzutsev 2014). Furthermore, Poland received a Circassian request for recognition of the genocide on the Polish Independence Day on November 11, 2014 (NatPress 2014a). Also, in March 2015 the presidents, prime ministers and speakers of the parliament of Estonia (Justice for North Caucasus 2015) and Lithuania (Cherkess.net 2015), respectively, received joint appeals for recognizing the genocide from Circassians in the North Caucasus and in the diaspora.

These appeals have not been uncontested within the activist groups themselves. There is still a certain split between diaspora activists and radical representatives in the homeland, on the one hand, and more moderate and mainstream elements in the homeland, on the other. The head of Adyge Hase in Krasnodar, Asker Sokht, was critical of initiatives directed at foreign countries (Circassia Times 2014b). In his opinion the question of recognition of the Circassian genocide is an internal issue that should be discussed within Russia. He pointed out that there were other organizations that shared his standpoint, such as Adyge Hase in 
Adygeya and Kuban. Another Circassian activist, Andzor Kabard, holds a different opinion and maintains that there is solid popular support among the Circassian diaspora in particular but also among Circassians in the homeland generally (Circassia Times 2014).

\section{The Empire strikes back - or refrains from doing so?}

Activists in the North Caucasus who have been engaged in the appeals to Ukraine, Poland and other countries have experienced some renewed pressure from the Russian authorities. To mention one example, the editor-in-chief of NatPress, Aslan Shazzo, was interrogated by the authorities for having published articles on the appeals (Natpress 2014b). Valery Dzutsev, an international expert on the Circassian movement, sees however signs of a recent strengthening of the position of homeland Circassians in relation to their authorities. Although harassment of Circassian activists does occur, this is not carried out with full force, he says. According to him, the Russian authorities seem to have chosen 'a low-key containment strategy' in fear of a backlash from Circassians in the North Caucasus and in the diaspora. It is in this light that he assesses the fact that a large international delegation of Circassians from Turkey and other countries was touring the North Caucasian republics (but not Sochi and Krasnaya Polyana) taking part in mourning ceremonies organized in connection with the Day of Remembrance on May 21, 2015. Dzutsev thinks that recent developments in the North Caucasus and Turkey suggest that 'Moscow regards the Circassians as a serious force that cannot be easily suppressed without repercussions’ (Dzutsev 2015).

The Circassian quest for genocide recognition is made additionally complex by its coincidence with the globally more well known struggle for recognition of the Armenian genocide in 1915. In the commemoration of the centenary of the Armenian tragedy, Vladimir Putin participated in ceremonies in Armenia, while declining invitations to come to Turkey. He even used the term genocide in his address to the Armenians: 
April 24, 2015 is a sorrowful date linked to one of the most tragic and dramatic events in the history of humanity - the genocide of the Armenian people. One hundred years later, we bow our heads before the memory of all victims of this tragedy, which our country has always seen as its own pain and sorrow. (Putin 2015)

The issue was on the agenda of the Russian parliament on April 24, 2015, whereby a resolution was passed that described the massacre of Armenians that took place in 1915 as genocide (Gosudarstvennaya Duma, 2015). Turkey’s president Erdoğan as well as the Turkish Ministry of Foreign Affairs reacted strongly to the Russian use of the controversial term, indicating rather clearly that here the pot was trying to call the kettle black (Ministry of Foreign Affairs, Republic of Turkey, 2015). By the same token, Halis Din, board member of the Circassian Association Federation in Turkey, reacted to Putin's use of the g-word with respect to the Armenian tragedy while ignoring the Circassian quest for recognition of the genocide:

Russia needs to confront their own history, recognize the murder of Circassians as genocide and compensate them for their exile. [...] We are calling out to Putin and the entire Russian government to open up the archives, recognize the Circassian genocide, and compensate for the genocide and the exile that continues today (World bulletin.net 2015).

It is hard to tell whether the Circassian quest for recognition of the genocide has benefitted from or been hindered by the points of convergence with the Armenian genocide and the coincidence in time with the vocal campaign for its recognition. Whereas the Armenian campaign has developed into high politics and caught worldwide attention, the Circassians have been more low-key in promoting their cause. One may perhaps suspect that the Circassians efforts may have become less noticed by the world because of the turbulence surrounding the Armenian issue. To the extent that the two campaigns can be coordinated there may be benefits for the Circassian activists, but often, in view of the intricacies of 
Russo-Turkish relations the gains may seem uncertain. That is why the Sochi Olympics and the run-up to them were so valuable for the Circassians. For a short while there, they had the undivided attention of the global audience.

\section{Conclusion}

How successful were then the Circassians in advancing their demands in conjunction with the Sochi Winter Games in 2014? It is difficult to assess how much the global attention around the Games has actually promoted the Circassian cause and how big its impact on the Circassian movement will be in a longer perspective. Even if some internal divisions remain within the Circassian movement, the campaign against the Sochi Winter Games has served to mobilize Circassians internally, strengthened their articulation of a common identity and helped them to raise the international awareness of their hitherto marginalized conditions of existence. In that sense, for all the losses of prestige and the disrespect incurred through the organization of the Sochi Olympics on the lands of their ancestors' graves, the Circassians may therefore on balance and on a collective level have seemed to benefit from the Sochi mega-event.

In terms of the lobbying for their cause the Circassian activists groups especially in the diaspora were active both in terms of issue-framing and attempted agenda-setting. The Russian warfare in the North Caucsaus in the mid-19 ${ }^{\text {th }}$ century was framed as genocide, and its recognition as genocide was put on the international agenda for discussion. It seems that the Circassians managed to carve out a niche of their own and gain international attention for it. The activities of the Circassian groups were noted by a global audience, and if Goble was right that few independent reporters on the eve of the Games could write about the Sochi Olympics without making some reference to the crimes historically committed against the indigenous population, this was certainly a great success for the lobbyists. 
By implication it would seem that the Circassian activists' goodwill gains add up to a corresponding loss of prestige on the part of the Putin administration. The Russian authorities have not taken lightly to the attempts of Circassians to use their fifteen minutes of fame to maximize the attention to their cause from abroad. This global attention may have served partly to shield the Circassian activists from full-blown repression, but this effect may well trail off rather quickly.

At times the Circassians have played a game with uncertain outcomes and high stakes. The appeals for recognition of the Circassian genocide addressed to the Georgian, Ukrainian and Estonian parliaments and governments, were symbolic in more than one respect. Symbolic politics were certainly there as the aim was to gain recognition of the genocide, the question of which has come to be a centerpiece of the Circassians' common identity construction. In addition, however, symbolic politics were also involved in turning to what on an official rhetorical level is treated as Russia's external adversaries. This may have prompted the Russian authorities to play it tough against individual Circassians activists.

It is hard to tell what made the Circassian activists turn their appeals to the Ukrainian political leadership in the midst of the tense international situation over Ukraine and the Western criticism of Russia’s obvious but non-admitted involvement in the crisis. They must have known that this move, quite in analogy to the appeal for genocide recognition to the Georgian parliament in 2010, was likely to antagonize the Putin regime. Were their actions then made because of their perception that the Circassian movement thanks to the Sochi Olympics had gained so much momentum that it could afford to advance its positions further? Or were they this time rather due to a feeling of frustration that the fifteen minutes of fame were long gone and were not likely to return?

For some while yet, the awareness of the existence of the Circassian indigenous population in North Caucasus, partly living on in the homeland under harsh conditions but 
above all remaining in the diaspora, will linger in the minds of the international public opinion. For how long this effect will remain no one knows, but it is safe and indeed also trite to assume that the effects of the fifteen minutes of fame will subside as time goes by. However, through their common activities the Circassians have gained both in dignity and respect also internally. Rather than the greater but receding receptivity on the part of the elusive public opinion abroad this factor may be what ultimately helps the Circassian movement in achieving international acknowledgement of their identity claims in the future.

\section{References}

Adyge Heku. 2013. "Obrashchenie cherkesskikh organizatsii Adygei, KChR i Krasnodarskogo kraya k Prezidentu RF i Federalnomu Sobraniyu RF.” May 2. Accessed January 24, 2015. www.aheku.net/news/society/3542

Adygi.ru. 2011. "Obrashchenie Prezidenta RF B.N. Eltsina k narodam Kavkaza v svyazi co 130-letiem Kavkazskoi voine.” October 10. Accessed February 20, 2015. http://adygi.ru/index.php?newsid=9937

Auten, Brian J. 2006. "Political Diasporas and Exiles as Instruments of Statecraft." Comparative Strategy 25 (3): 329-341.

Bacchi, Umberto. 2014. "Sochi Winter Olympics: Circassian Protest Website NoSochi2014 Hacked on Games’ Eve.” Yahoo News UK/Ireland, February 7. https://uk.news.yahoo.com/sochi-winter-olympics-circassian-protest-website-nosochi2014hacked-133138174.html\#xr9ziUw

Besleney, Zeynel Abidin. 2010. “Circassian Nationalism and the Internet” Open Democracy, May 21. https://www.opendemocracy.net/od-russia/zeynel-abid in-besleney/circassiannationalism-and-internet

Besleney, Zeynel Abidin. 2014. Circassian Diaspora in Turkey. A Political History. London: Routledge.

Bullough, Oliver. 2012. "Sochi 2014 Winter Olympics: The Circassians Cry Genocide.” Newsweek, May 21. www.newsweek.com/sochi-2014-winter-olympics-circassians-crygenocide-64893

Cherkess.net. 2015. "A Request for Recognizing the Circassian Genocide committed by the Tsarist Russian Empire”. March 12. http://cherkessia.net/bakisacimiz.php?id=3386 
Circassia Times. 2014. "The Circassian question has never been and will not be an internal affair of Russia”. October 9. Accessed June 2, 2015.

http://circassiatimesenglish.blogspot.com/2014/10/the-circassian-question-has-neverbeen.html

Dzutsev, Valery. 2014. "Ukraine Shows Readiness to Pay More Attention to Oppressed Groups in Russia.” North Caucasus Analysis, June 23. Accessed June 2, 2015.

http://www.jamestown.org/single/?tx_ttnews\%5Btt_news\%5D=42537\&no_cache=1\#.VW8MksuGAE

—. 2015. "Circassian Activists in Russia Become a Serious Force.” North Caucasus Weekly, June 1. Accessed June 2, 2015. www.jamestown.org/programs/nc/single/ ?tx_ttnews\% 5Btt_news\%5D=43982\&tx_ttnews\%5BbackPid\%5D=24\&cHash=3a808a7e6d7a9a34e570b2 8e4033caa9

Entman, Robert M. 2004. Projections of Power: Framing News, Public Opinion, and US Foreign Policy. Chicago: The University of Chicago Press.

Gilroy, Paul. 1994. “Diaspora.” Paragraph, 17(3): 207-212.

Goble, Paul. 2015. "151 Years After the Genocide and One Year After Sochi, the Circassian Issue Isn’t Going Away.” The Interpreter, May 23. Accessed May 24, 2015.

www.interpretermag.com/151-years-after-the-genocide-and-one-year-after-sochi-thecircassian-issue- isnt-going-away/

Gosudarstvennaya Duma. 2015. "Stenogramma zasedaniya 24 aprelya 2015 g.” Accessed May 31, 2015. http://transcript.duma.gov.ru/node/4275/\%29

Gutkin, Mikhail. 2014. "Rossiiskie cherkesy: Olimpiada otkryvaet vozmozhnosti” Golos Ameriki, February 22. http://www.golos-ameriki.ru/content/circassian-olympic-gamessochi/1857166.html

Hägel, Peter, and Pauline Peretz. 2005. "States and Transnational Actors: Who's Influencing Whom? A Case Study in Jewish Diaspora Politics during the Cold War.” European Journal of International Relations 11 (4): 467-93.

Hansen, Lars Funch. 2013. "Sochi as a Site of Circassian Long-Distance Memorialisation.” In The Sochi Predicament: Contexts, Characteristics and Challenges of the Olympic Winter Games in 2014, edited by Bo Petersson, and Karina Vamling, 95-123. Newcastle upon Tyne: Cambridge Scholars Publishing.

—. 2014. The Circassian Revival: A quest for recognition, mediated transnational mobilisation and memorialization among a geographically dispersed people from the Caucasus. PhD Diss., University of Copenhagen.

Jaimoukha, Amjad. 2001. The Circassians. Richmond: Curzon Press.

—. 2014. "The Circassian Cultural Centre "Circassian House" has been inaugurated in Sochi Olympic Park” Circassian Culture and Folklore, February 4. Accessed June 21, 2015. http:/jaimoukha.blogspot.com/2014/02/the-circassian-cultural-centre.html 
Justice for North Caucasus. 2015. "New filing with Estonia to recognize the Circassian genocide”. March 11. http://justicefornorthcaucasus.info/?p=1251675134

Kapaeva, Asia. 2014. "V Stambule bole shestidesyati chelovek vyshli na aktsiyu protiv presledovaniya organizatora antiolimpiiskoi aktsii v KBR.” Kavkazskii Uzel, June 22. Accessed January 4, 2015. http//kabardino-balkaria.kavkaz-uzel.ru/articles/244679/

Kaya, Ayhan. 2004. "Political participation strategies of the Circassian diaspora in Turkey." Mediterranean Politics 9(2): 221-239.

—. 2014. "The Circassian Diaspora in and Outide Turkey.” Problems of Post-Communism 61(4): 50-65.

Keck, Margareth E., and Kathryn Sikkink. 1998. Activists beyond Borders: Advocacy Networks in International Politics. Ithaca and London: Cornell University Press.

Kornya, Anastasiya. 2015. “Administratsiya prezidenta zaplatit za prorabotku novykh vozmozhnykh ugroz natsionalnoi bezopasnosti” Vedomosti, June 22. Accessed June 27, 2015. www.vedomosti.ru/politics/articles/2015/06/23/597522-administratsiya-prezidenta-zaplatitza-prorabotku-novih-vozmozhnih-ugroz-natsionalnoi-bezopasnosti

Kreiten, Irma. 2009. "A colonial experiment in cleansing: the Russian conquest of Western Caucasus, 1856-65.” Journal of Genocide Research, 11(2-3), June-September, 213-241.

Lagunina, Irina. 2007. "Pochemu cherkesy protiv Olimiady v Sochi” Radio Svoboda, December 18. www.svoboda.org/content/transcript/426976.html

Ministry of Foreign Affaires. Republic of Turkey. 2015. "No: 129, 24 April 2015, Press Release Regarding the Approach of the Russian Federation on the 1915 Events." http:/www.mfa.gov.tr/no_-129_-24-april-2015_-press-release-regarding-the-approach-of-therussian-federation-on-the-1915-events.en.mfa

Minnaert, Lynn. 2012. "An Olympic legacy for all? The non-infrastructural outcomes of the Olympic Games for socially excluded groups (Atlanta 1996-Beijing 2008).” Tourism Management 33(2): 361-370.

NatPress. 2014a. "A request to recognize the Circassians genocide was sent to Poland on its Independence Day.” November 13. Accessed December 14, 2014. www.natpressru.info/ index.php? newsid=9244

—. 2014b. "Glavu 'Natpress' snova vyzyvali v tsentr 'E' po prosbam priznat genotsid cherkesov.” November 21. Accessed December 15, 2014. www.natpressru.info/ index.php? newsid=9266

Özgür, Ergün. 2011. "The North Caucasian and Abkhaz Diasporas; Their Lobbying Activities in Turkey.” In Caucasus Studies: Migration, Society and Language, Caucasus Studies 4, edited by Karina Vamling, 80-87. Dept. of Language, Migration and Society, Malmö University. 
Papşu, Murat. 2005. "Çerkes Dillerine Genel Bir Bakış” [A Quick look at the state of the Circassian languages]. Nart 3. www.kafkasfederasyonu.org/kultursanat/anadil/ cerkes_dilleri.htm

Parliament of Georgia. 2011. "Resolution of the Parliament of Georgia On the Recognition of Genocide of Circassians by the Russian Empire.” May 31. Accessed February 20, 2015. http:/parliament. ge/en/media/axali-ambebi/resolution-of-the-parliament-of-georgia-on-therecognition-of-genocide-of-circassians-by-the-russian-empire-28184.page

Persson, Emil. 2013. "Olympism and Empire: The Olympic myth in the contestation of the Caucasus.” In The Sochi Predicament: Contexts, characteristics and challenges of the Olympic Winter Games 2014, edited by Bo Petersson, and Karina Vamling, 72-94. Newcastle upon Tyne: Cambridge Scholars.

Petersson, Bo, and Elena Sommers. 2015. "Cold War to the Rescue? Anti-American Sentiment in Russian Highest Level Political Discourse”, Paper for the 20th Annual ASN World Convention, Columbia University, 23-25 April 2015

Petersson, Bo, and Karina Vamling. 2013. "The Sochi Winter Olympic Games: Walking a Tightrope?” In The Sochi Predicament: Contexts, characteristics and challenges of the Olympic Winter Games 2014, edited by Bo Petersson, and Karina Vamling, 1-19. Newcastle upon Tyne: Cambridge Scholars.

Polovinkina, T. (undated) "Shapsugskii natsionalnyi okrug (1924-1945).” Circassian Land. Accessed June 20, 2015. http://circassian.narod.ru/rus/circass/hist/shapsug.htm

Putin, Vladimir. 2014. "Meeting with the Public Council for the Preparation of the 2014 Winter Olympics, February 10, 2014”. President of Russia, February 10. Accessed February 17, 2015 http://eng.kremlin.ru/news/6642

—. 2015. "Greetings to the commemorative evening A World Without Genocide." President of Russia, April 22. Accessed May 21, 2015. http://en.kremlin.ru/events/president/news/ $\underline{49320}$

Richmond, Walter. 2013. The Circassian Genocide. New Brunswick: Rutgers University Press.

Somra, Gena, and Ivan Watson. 2014. "Circassians: Sochi Olympians 'are skiing on the Bones of our Ancestors'.” CNN, February 18. Accessed May 16, 2015. http:/edition.cnn.com/2014/02/18/world/russia-sochi-circassians/

Taylor, Charles. 1994. "The politics of recognition.” In Multiculturalism: Examining the politics of recognition, edited by Charles Taylor, and Amy Gutmann, 25-74. Princeton University Press.

Vserossiiskaya perepis naseleniya. 2010. Accessed February 20, 2015. www.gks.ru/free_doc/new_site/perepis2010/croc/perepis_itogi1612.htm 
World Bulletin.net. 2015. "Circassia: Putin should recognise Circassian genocide.” April 24. Accessed May 28, 2015. www.worldbulletin.net/world/158273/circassia-putin-shouldrecognise-circassian-genocide

YouTube. 2007. Full version of Putin speech (2014 Winter Olympics), Russia Today. https://www.youtube.com/watch?v=_aNo3DxWaW4

Zhemukhov, Sufian. 2012. "The birth of modern Circassian nationalism." Nationalities Papers, 40(4): 503-524. 